\title{
ISOLATION AND CHARACTERIZATION OF A MOLYBDENUM-REDUCING AND PHENOLIC- AND CATECHOL-DEGRADING Enterobacter sp. STRAIN SAW-2
}

\author{
MOHD KHALIZAN SABULLAH ${ }^{1,2^{*}}$, MOHD FADHIL RAHMAN ${ }^{2}$, SITI AQLIMA AHMAD ${ }^{2}$, \\ MOHD ROSNI SULAIMAN ${ }^{3}$, MOHD SHUKRI SHUKOR ${ }^{1}$, AZLAN JUALANG GANSAU ${ }^{1}$, \\ NOR ARIPIN SHAMAAN ${ }^{5}$ and MOHD YUNUS SHUKOR ${ }^{2}$ \\ ${ }^{1}$ Faculty of Science and Natural Resources, Universiti Malaysia Sabah, Kota Kinabalu 88400, Sabah, Malaysia \\ ${ }^{2}$ Department of Biochemistry, Faculty of Biotechnology and Biomolecular Sciences, Universiti Putra Malaysia, \\ Serdang 43400, Selangor, Malaysia \\ ${ }^{3}$ Faculty of Food Science and Nutrition, Universiti Malaysia Sabah, Kota Kinabalu 88400, Sabah, Malaysia \\ ${ }^{4}$ Snoc International Sdn Bbd, Lot 343, Inland Port 71800, Negeri Sembilan, Malaysia \\ ${ }^{5}$ Faculty of Medicine and Health Sciences, Islamic Science University of Malaysia, Kuala Lumpur 55100, Malaysia
}

Received 21 October 2015/Accepted 10 August 2016

\begin{abstract}
Molybdenum is an emerging pollutant worldwide. The objective of this study is to isolate molybdenum-reducing bacterium with the ability to grow on phenolic compounds (phenol and catechol). The screening process was carried out on a microplate. The bacterium reduced molybdenum in the form of sodium molybdate to molybdenum blue (Mo-blue). The bacterium required a narrow $\mathrm{pH}$ range for optimal reduction of molybdenum, i.e. between $\mathrm{pH} 6.3$ and 6.8, with temperature between 34 and $37^{\circ} \mathrm{C}$. Molybdate reduction to Mo-blue was best supported by glucose as the carbon source. However, both phenol and catechol could not support molybdate reduction. Other requirements for molybdate reduction included sodium molybdate concentrations between 15 and $30 \mathrm{mM}$, and phosphate concentration of $5.0 \mathrm{mM}$. The bacterium exhibited a Mo-blue absorption spectrum with a shoulder at $700 \mathrm{~nm}$ and a maximum peak near the infrared region at $865 \mathrm{~nm}$. The Mo-reducing bacterium was partially identified as Enterobacter sp. strain Saw-2. The capability of this bacterium to grow on toxic phenolic compounds and to detoxify molybdenum made it a significant agent for bioremediation.
\end{abstract}

Keywords: Catechol, Enterobacter sp., Molybdenum, molybdenum blue, phenol

\section{INTRODUCTION}

Heavy metals are toxic to organisms. Some microorganisms are able to detoxify heavy metals by employing mechanisms such as biosorption, sequestration or chelation, active pumping and reduction (Batta et al. 2013; Oves et al. 2013; Banerjee et al. 2016). Microorganisms having capability to reduce heavy metals such as chromium, molybdenum mercury into less toxic forms were documented. Molybdenum (Mo) is essential to organisms as it is a cofactor to many important enzymes such as nitrogenase, sulfite oxidase, aldehyde oxidase and xanthine oxidoreductase (Daniels et al. 2008; Leimkühler et

\footnotetext{
* Corresponding author: ejanz_sart2@yahoo.com
}

al. 2011). Molybdenum is not generally toxic to human. However, molybdenum is very toxic to ruminants, such as sheep and cattle at concentrations as low as several parts per million (ppm). An elevated level of molybdenum in ruminants causes a disease known as hypercuprosis (Ward 1978). Recent data showed that molybdenum is toxic to spermatogenesis and embryogenesis in animals, including catfish and mice (Meeker et al. 2008; Bi et al. 2013; Zhai et al. 2013; Zhang et al. 2013). Toxic effect of molybdenum to these animals warrants removal of molybdenum from the environment. Heavy usage of molybdenum in various steel products and lubricants resulted in high concentration of molybdenum reaching hundreds of ppm in the water bodies of the Black Sea and Tokyo Bay 


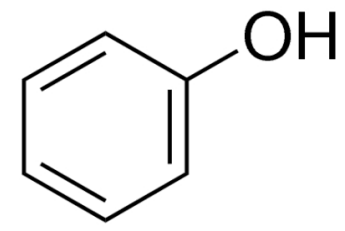

(a) Phenol

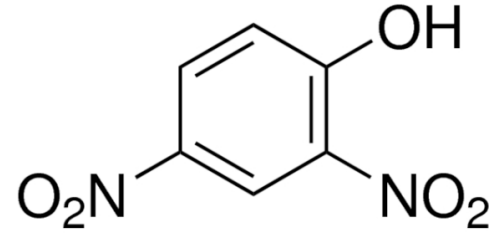

(b) Catechol

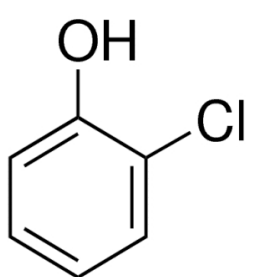

(c) 2-chlorophenol

Figure 1 Chemical structure of some toxic phenolic compounds

(Davis 1991; Neunhäuserer et al. 2001). Terrestrially, in the mine tailings of a molybdenum mine in New Mexico, as high as 2,000 ppm of molybdenum concentration were documented (Runnells et al. 1976). Together with heavy metals, oil, grease and phenolics are hydrocarbon which are reported to be the number one scheduled waste (Yadzir et al. 2016). Phenol and phenolic compounds (Fig. 1) are not only toxic to human, but also to many other organisms (Shukor et al. 2008a; Shukor et al. 2008b; Rahman et al. 2009; Yunus et al.2009).

The presence of multiple pollutants requires microorganisms with multiple detoxification ability. Thus, the objective of this study is to isolate such a microorganism. In this study, we reported on the isolation of a molybdenumreducing bacterium with the ability to grow on phenolic compounds (phenol and catechol).

\section{MATERIALS AND METHODS}

\section{Chemicals}

Chemicals such as $\mathrm{Na}_{2} \mathrm{MoO}_{4} \cdot 2 \mathrm{H}_{2} \mathrm{O}$, $\mathrm{MgSO}_{4} \cdot 7 \mathrm{H}_{2} \mathrm{O},\left(\mathrm{NH}_{4}\right)_{2} \cdot \mathrm{SO}_{4}, \mathrm{NaCl}$ and $\mathrm{Na}_{2} \mathrm{HPO}_{4}$ were purchased from Sigma Aldrich (St. Louis, MO, USA) and were of analytical grade while glucose and yeast extract were purchased from Fisher (Malaysia).

\section{Isolation of Molybdenum-Reducing Bacterium}

Molybdenum-reducing bacterium was isolated using two kinds of media, i.e. low phosphate molybdate (LPM) and high phosphate molybdate (HPM) media. LPM medium consists of the following composition: $\mathrm{MgSO}_{4} \cdot 7 \mathrm{H}_{2} \mathrm{O} \quad(0.05 \%$ $\mathrm{w} / \mathrm{v}), \mathrm{Na}_{2} \mathrm{MoO}_{4} \cdot 2 \mathrm{H}_{2} \mathrm{O}(0.206 \%$ or $10 \mathrm{mM})$, yeast extract $(0.05 \% \mathrm{w} / \mathrm{v}),\left(\mathrm{NH}_{4}\right)_{2} \cdot \mathrm{SO}_{4}(0.3 \% \mathrm{w} / \mathrm{v})$, glucose $(1 \% \quad \mathrm{w} / \mathrm{v}), \mathrm{NaCl}(0.5 \% \quad \mathrm{w} / \mathrm{v})$ and $\mathrm{Na}_{2} \mathrm{HPO}_{4}(0.071 \% \mathrm{w} / \mathrm{v}$ or $5 \mathrm{mM})$. The LPM medium was adjusted to $\mathrm{pH}$ 7.0. Agar having concentration of $1.5 \%(\mathrm{w} / \mathrm{v})$ was added to the LPM solid media. Bacterial cell harvesting from the LPM medium could not be carried out, as blue aggregates formed in the LPM liquid media. Hence, the phosphate concentration was increased to $100 \mathrm{mM}$ which made the medium became HPM (Ghani et al. 1993). Soil materials for the isolation of Molybdenum-reducing bacteria were taken from topsoil depth of $5 \mathrm{~cm}$ in a polluted area in Kuching, Sarawak $\left(1.6077^{\circ} \mathrm{N}\right.$, $110.3785^{\circ} \mathrm{E}$ ) in April, 2011. A cell suspension containing $1 \mathrm{~g}$ of soil and $10 \mathrm{~mL}$ of sterile distilled water was prepared. Soil suspension of $0.1 \mathrm{~mL}$ aliquot was immediately spread on an agar plate containing LPM media. The plates were incubated for 48 hours at room temperature $\left(27^{\circ} \mathrm{C}\right)$. Several white and blue colonies appeared afterwards. Colony with the strongest blue intensity was restreaked on LPM agar until a pure culture was obtained. HPM media was utilized to prepare for the resting cells of the molybdenumreducing bacterium. Growth of the bacterium was carried out in a $1 \mathrm{~L}$ culture volume, shaken using orbital shaker, set at $120 \mathrm{rpm}$, and incubated for 48 hours at room temperature $\left(27^{\circ} \mathrm{C}\right)$. Cells were harvested via centrifugation $(10,000 \mathrm{xg}$, for 10 minutes). Distilled water was utilized to wash the bacterial pellets after centrifugation twice. The pellets were then resuspended in $10 \mathrm{~mL}$ of LPM media $(5 \mathrm{mM})$ with the glucose omitted.

\section{Preparation of Resting Cells}

Preparation and use of resting cells in a microtiter format were carried out based on Shukor and Shukor (2014). Cell suspension prepared previously $(180 \mathrm{~mL})$ was transferred to each well of a sterile microplate. Sterile glucose $(20 \mathrm{~mL})$ from a $10 \%(\mathrm{w} / \mathrm{v})$ stock solution was 
mixed with the cell suspension. The microplate was covered with a sterile sealing tape (Corning ${ }^{\circledR}$ microplate). The microplate was incubated at room temperature $\left(27^{\circ} \mathrm{C}\right)$ for 48 hours. Mo-blue production was determined at $750 \mathrm{~nm}$ in a microtiter plate reader Model No. 680, (BioRad, Richmond, CA). The specific extinction coefficient of $11.69 \mathrm{mM}^{-1} \mathrm{~cm}^{-1}$ was utilized to determine Mo-blue concentration (Shukor et al. 2003). Heavy metals such as lead (II), arsenic (V), mercury (II), silver (I), chromium (VI) copper (II) and cadmium (II) on Mo-blue production were obtained from Atomic Absorption Spectrometry (AAS) calibration solutions (Merck Chemical Co., Germany). The capability of phenolics to act as electron donors was tested using the microplate format. The phenolics tested were phenol, 2,4dinitrophenol, pentachlorophenol, 2chlorophenol, 4-chlorophenol, catechol, salicylic acid, 4-nonylphenol, p-hydroxybenzoic acid, benzoate and 2-napthol. The phenolics replaced glucose and were tested at $200 \mathrm{mg} / \mathrm{L}$, but in a volume of $50 \mathrm{~mL}$ (Arif et al. 2013). If the phenolics could be used as electron donors, Moblue production will increase. On the other hand, ability of the above phenolics to support the growth of this bacterium independently from molybdenum-reduction was carried out in HPM media minus molybdenum. The increase of bacterial growth after 48 hours of incubation at room temperature, which was an indication of phenolics assimilation, was measured at $600 \mathrm{~nm}$.

\section{Identification of the Molybdenum-Reducing Bacterium}

Standard biochemical tests according to the Bergey's Manual (Holt et al. 1994) was used to identify the Molybdenum-reducing bacterium. In addition, a software-based method (ABIS online system) was utilized to interpret the results (Costin \& Ionut 2015). Briefly. Briefly, the standard methods included gram staining, detection of motility via the hanging drop method, and various biochemical tests.

\section{Statistical Analysis}

Data analyses were carried out using Graphpad Prism v 6.0 (www.graphpad.com). The Student's t-test or ANOVA with Tukey's test as the post hoc analysis was carried out to compare means of groups.

\section{RESULTS AND DISCUSSION}

Bacterial molybdenum reduction to Mo-blue is a phenomenon that has been described for more than one hundred years and is a prospective bioremediation tool (Shukor et al. 2014). This phenomenon was initially observed in 1896 in E. coli bacterium (Levine 1925). Comprehensive research about this phenomenon was only started in 1985 in the E. coli K12 bacterium (Campbell et al. 1985). Later on, sodium molybdate reduction into Mo-blue by the Thiobacillus ferrooxidans bacterium, a chemolitotroph, was reported by Sugio et al. (1988) without mentioning the works of Campbell et al. (1985). This suggested the scarcity of publications on this phenomenon. Enterobacter cloacae strain 48 (EC 48) is the first bacterium isolated from the Malaysian soils with the capacity to reduce molybdate (Ghani et al. 1993). The first Molybdenum-reducing bacterium reported with the ability to detoxify other xenobiotics is the SDS-degrading Klebsiella oxtoca (Halmi et al. 2013). Isolation of more xenobiotics-detoxifying Molybdenum-reducing bacterium can expand the capability of existing isolates for bioremediation of sites containing molybdenum, together with other xenobiotics.

\section{Partial Identification of the Molybdenum- Reducing Bacterium}

The bacterium was Gram-negative, rodshaped and motile. The biochemical test results using the ABIS online software showed that bacterium having the highest homology $(90 \%)$ and the highest accuracy (97\%) was Enterobacter cloacae (Table 1).

The bacterium is tentatively named Enterobacter sp. strain Saw-2. Identification of the bacterium up to the species level can only be carried out through the addition of several more polyphasic methods, such as16S rRNA gene sequencing, DNA-DNA hybridization determination of genomic DNA $\mathrm{G}+\mathrm{C}$ content and fatty acid profile (Ahmad et al. 2013). Two molybdenumreducing bacteria from this genus, i.e. Enterobacter cloacae strain 48 (Ghani et al. 1993) and Enterobacter sp. strain Dr.Y13 (Shukor et al. 2009) were previously reported. A bacterium from this genus has been reported for having ability to tolerate high concentrations of heavy metals such as nickel, cadmium and lead at levels of up to 700, 
Table 1 Biochemical tests for Enterobacter sp. strain Saw-2

Motility
Pigment
Catalase production ( $24 \mathrm{~h})$
Oxidase ( $24 \mathrm{~h}$ )
ONPG (beta-galactosidase)
Arginine dihydrolase (ADH)
Lysine decarboxylase (LDC)
Ornithine decarboxylase (ODC)
Nitrates reduction
Methyl red
Voges-Proskauer (VP)
Indole production
Hydrogen sulfide (H2S)
Acetate utilization
Malonate utilization
Citrate utilization (Simmons)
Tartrate (Jordans)
Esculin hydrolysis
Gelatin hydrolysis
Urea hydrolysis
Deoxyribonuclease
Lipase (com oil)
Phenylalanine deaminase

$\begin{array}{ll}+ & \text { Acid production from: } \\ - & \text { Alpha-Methyl-D-Glucoside } \\ + & \text { D-Adonitol } \\ - & \text { L-Arabinose } \\ + & \text { Cellobiose } \\ + & \text { Dulcitol } \\ - & \text { Glycerol } \\ + & \text { D-Glucose } \\ + & \text { myo-Inositol } \\ \text { d } & \text { Lactose } \\ + & \text { Maltose } \\ - & \text { D-Mannitol } \\ - & \text { D-Mannose } \\ + & \text { Melibiose } \\ + & \text { Mucate } \\ + & \text { Raffinose } \\ + & \text { L-Rhamnose } \\ + & \text { Salicin } \\ \text { d } & \text { D-Sorbitol } \\ + & \text { Sucrose (Saccharose) } \\ - & \text { Trehalose } \\ - & \text { D-Xylose } \\ - & \end{array}$

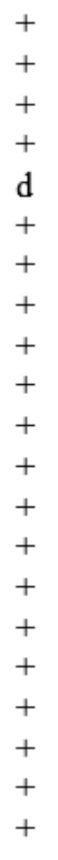

Notes: $+=$ positive result; $-=$ negative result; $\mathrm{d}=$ indeterminate result

900 and 1,100 ppm, respectively (Banerjee et al. 2015). This phenomenon suggested that being heavy metal tolerant and conducting heavy metal reduction are part of the strategies employed by bacteria from this genus to combat heavy metal toxicity. Nickel was detected to be more toxic $(700$ ppm), followed by cadmium (900 ppm) and lead $(1,100 \mathrm{ppm})$. Optimal $\mathrm{pH}$ that supported molybdenum reduction was between 6.5 and 6.8 (Fig. 2), in temperature range of $34-37^{\circ} \mathrm{C}$ (Fig. 3).

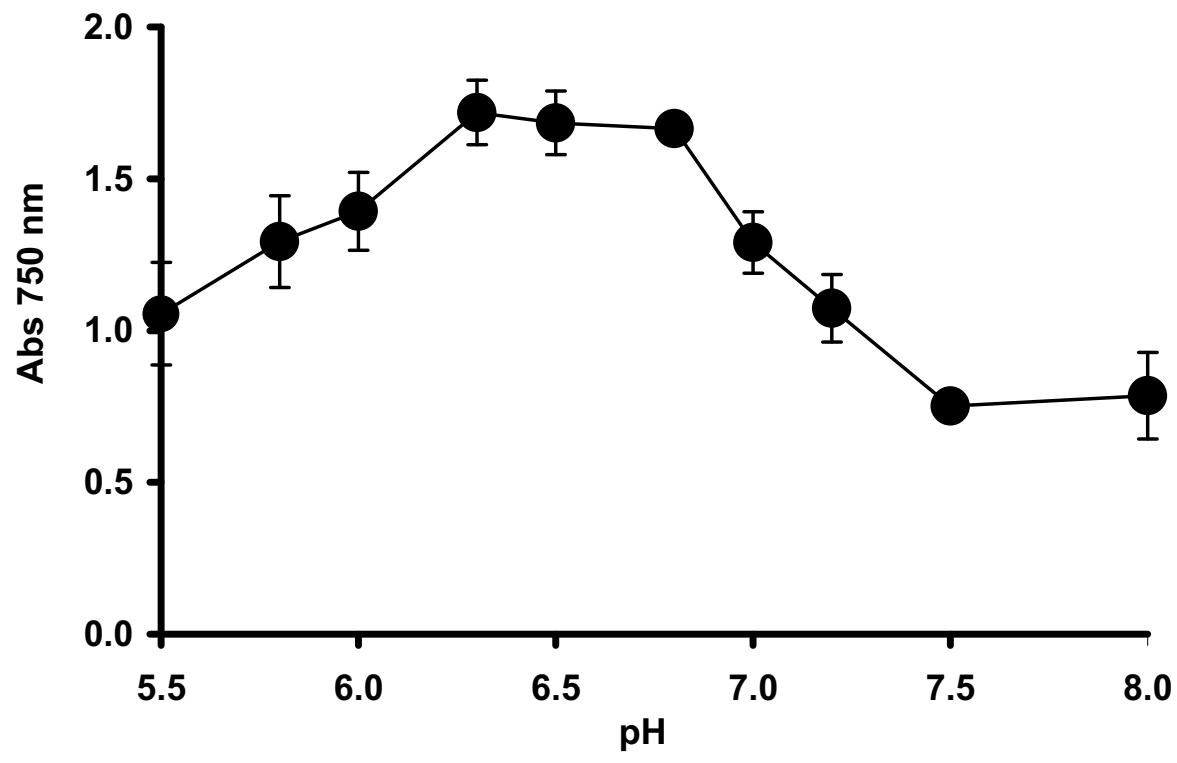

Figure 2 Effect of initial pH on molybdenum reduction by Enterobacter sp. strain Saw-2 Note: Error bars represent mean \pm standard deviation $(\mathrm{n}=3)$ 


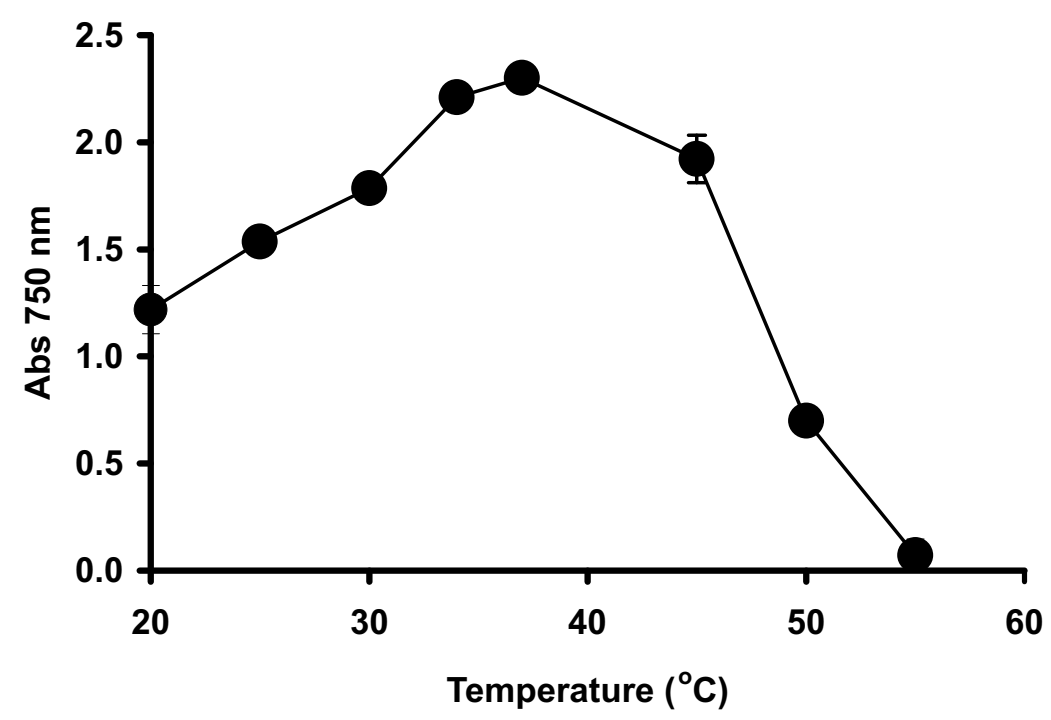

Figure 3 Effect of temperature on molybdenum reduction by Enterobacter sp. strain Saw-2 Note: Error bars represent mean \pm standard deviation $(\mathrm{n}=3)$

High-throughput method using a microplate format was employed in this study. This method can accelerate characterization works, while acquiring more information as opposed to the regular shake-flask method (Iyamu et al. 2008; Shukor \& Shukor 2014). The use of resting cells for studying Mo-blue production was initiated in EC 48 (Ghani et al. 1993). Resting cells were also used in studying heavy metals reduction such as in chromate (Llovera et al. 1993), selenate (Losi \& Jr
1997) and xenobiotics biodegradation such as diesel (Auffret et al. 2015) and phenol (Sedighi \& Vahabzadeh 2014).

\section{Molybdenum Absorbance Spectrum}

The scanning absorption spectrum of the resultant Mo-blue from Enterobacter sp. strain Saw-2 showed a maximum peak at $865 \mathrm{~nm}$, and a characteristic shoulder at about $700 \mathrm{~nm}$ (Fig. 4).

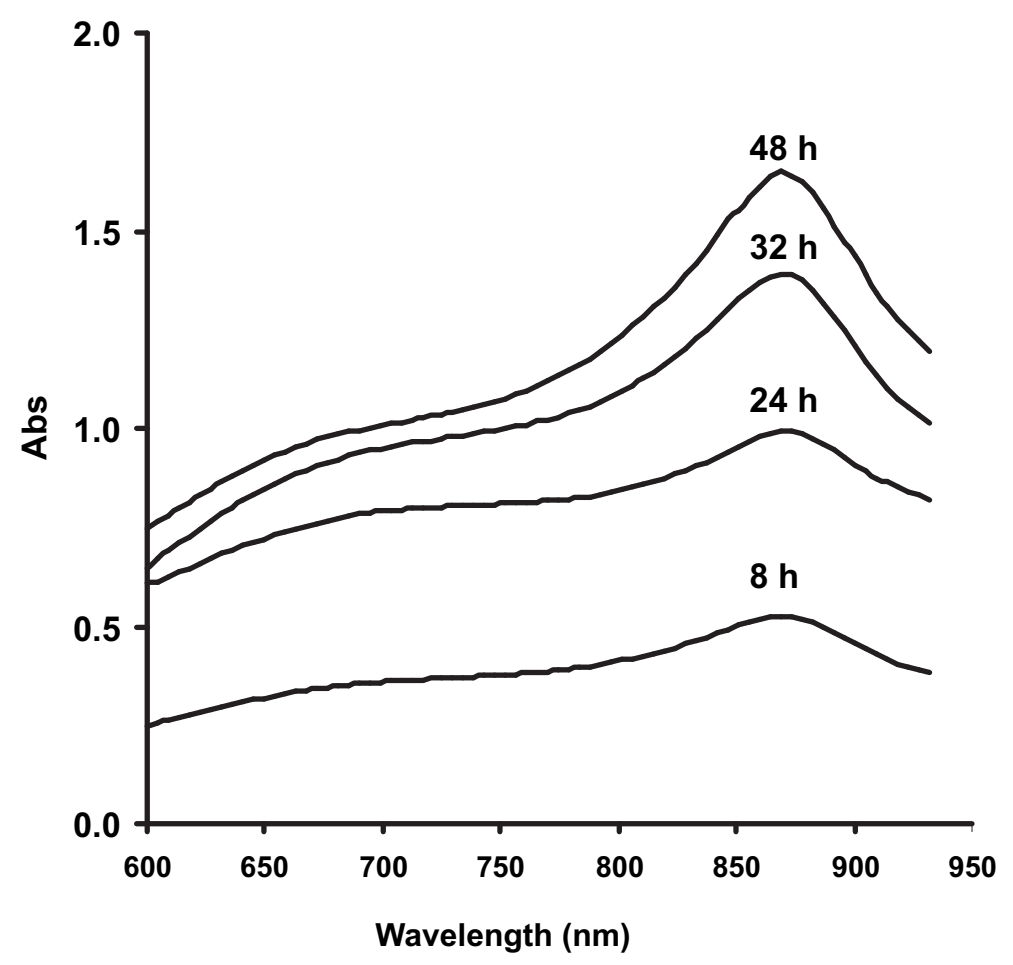

Figure 4 Scanning absorption spectrum of Mo-blue from Enterobacter sp. strain Saw-2 at different time intervals 
It was observed that the resulting spectrum resembled the spectrum of the Mo-blue produced by the phosphate determination method (Clesceri et al. 1989). Spectrum produced by phosphate determination exhibited a maximum absorption around 880 to $890 \mathrm{~nm}$. A characteristic shoulder was seen around 700 to $720 \mathrm{~nm}$ (Hori et al. 1988). All of the Mo-blue spectra from previously isolated Molybdenum-reducing bacteria showed similar spectra. Based on this knowledge, a hypothesis was developed for this study i.e. molybdenum reduction should proceed via the intermediate phosphomolybdate (Shukor et al. 2007). Another basis for the hypothesis was the confirmation of the presence of phosphomolybdate species through spectrophotometric analysis of the resultant absorption spectrum (Sims 1961; Yoshimura et al. 1986; Hori et al. 1988).

Aside from the demonstration of the unique spectroscopic profile of the blue product, the presence of Mo-blue by itself can visually prove that molybdenum reduction has taken place. Reduced phosphomolybdate or Mo-blue has a fractional oxidation state between $6+$ and $5+$ (Sidgwick 1951; Kazansky \& Fedotov 1980). Other metals, such as mercury and chromate, show no visible color when experiencing reduction through bacterial process (Suzuki et al. 1992). Therefore, confirmation of reduction has to be carried out through EPR-Electron Paramagnetic Resonance (Suzuki et al. 1992). The presence of an intermediate species is not unique to Mo-blue production, as this is also reported in bacterial chromate reduction, such as bacteria Pseudomonas ambigua (Suzuki et al. 1992) and Shewanella putrefaciens (now known as S. oneidensis) (Myers et al. 2000). In these bacterial reduction processes, an intermediate species $\mathrm{Cr}^{5+}$ was observed (Myers et al. 2000).

\section{Effect of Electron Donor on Molybdate Reduction}

Molybdate reduction to Mo-blue was best supported by the sugar glucose. This was followed by sucrose, maltose, 1-rhamnose, raffinose, d-mannose, lactose, mucate, cellobiose, d-mannitol, d-adonitol, melibiose, glycerol, $\mathrm{d}$-sorbitol and l-arabinose in descending order (Fig. 5). Mo-blue production by other sugars such as dulcitol, salicin and myo-inositol were found to be not significantly different $(p>0.05)$ from control based on ANOVA with Tukey's test. Previous works demonstrated that Molybdenumreducing bacteria prefer simple assimilable sugars, such as sucrose, glucose and fructose (Campbell et al. 1985; Ghani et al. 1993; Rahman et al. 2009; Yunus et al. 2009; Shukor et al. 2009; A hmad et al. 2013; Othman et al. 2013; Abo-Shakeer et al. 2013). The metabolic pathways glycolysis, Kreb's cycle and electron transport chain were used to convert these sugars to NADH and NADPH. Both reducing equivalents are electron donating substrates for the molybdenum reducing-enzyme (Shukor et al.2014).

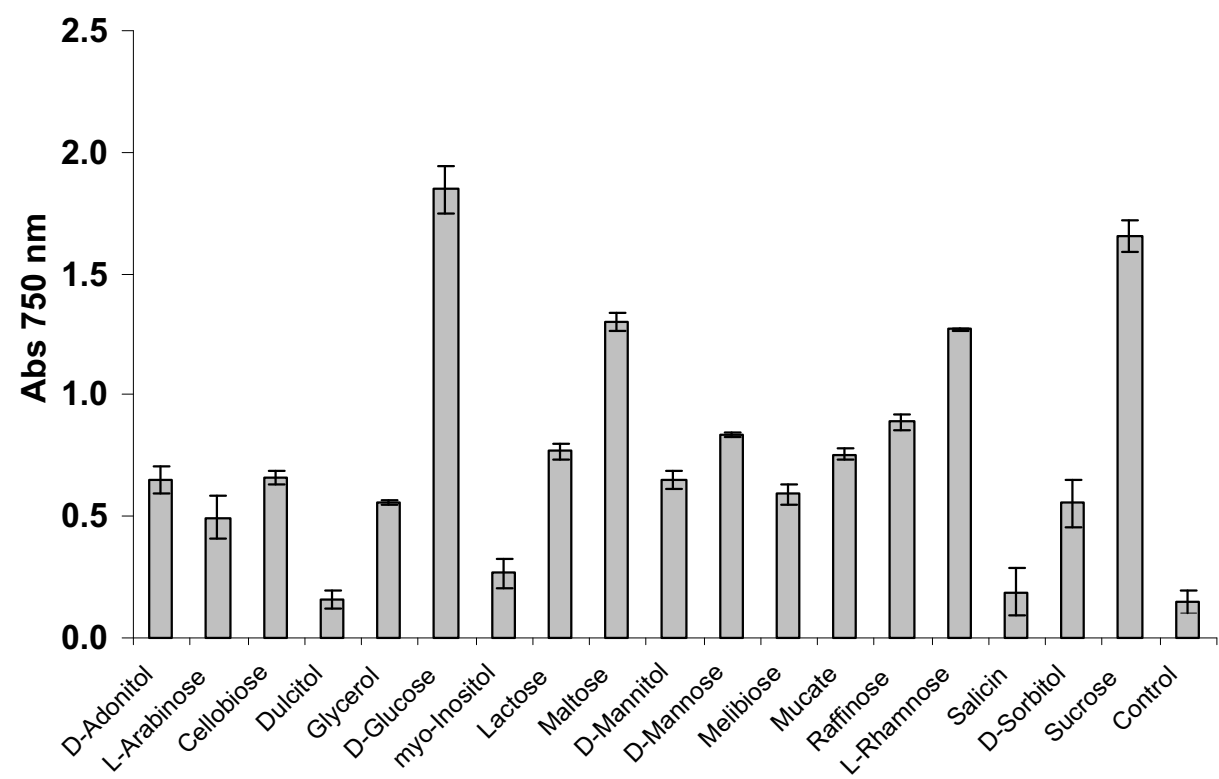

Figure 5 Effect of different electron donor sources $(1 \% \mathrm{w} / \mathrm{v})$ on molybdenum reduction Note: Error bars represent mean \pm standard deviation $(\mathrm{n}=3)$ 
Effect of Phosphate and Molybdate Concentrations to Molybdate Reduction

The optimal concentration of phosphate supporting optimal molybdenum reduction occurred at $5 \mathrm{mM}$. Concentrations higher than this dramatically ceased production of Mo-blue (Fig. 6). High phosphate concentrations inhibit the stability of phosphomolybdate, of which upon reduction, it is converted to Mo-blue Glenn \& Crane 1956; Sims 1961; Shukor et al. 2000). Molybdenum-reducing bacteria isolated previously are also strongly inhibited by phosphate concentration higher than $5 \mathrm{mM}$ (Shukor \& Syed 2010; Lim et al. 2012; Ahmad et al. 2013; Halmi et al. 2013; Othman et al. 2013; AboShakeer et al. 2013; Khan et al. 2014; Shukor et al. 2014).

Enterobacter sp. strain Saw-2 can tolerate and reduce molybdenum at sodium molybdate concentrations as high as $60 \mathrm{mM}$, but the production of Mo-blue was severely inhibited. The optimal concentrations of molybdate which supported the reduction, were between 15 and 30 $\mathrm{mM}$ (Fig. 7). The other Molybdenum-reducing

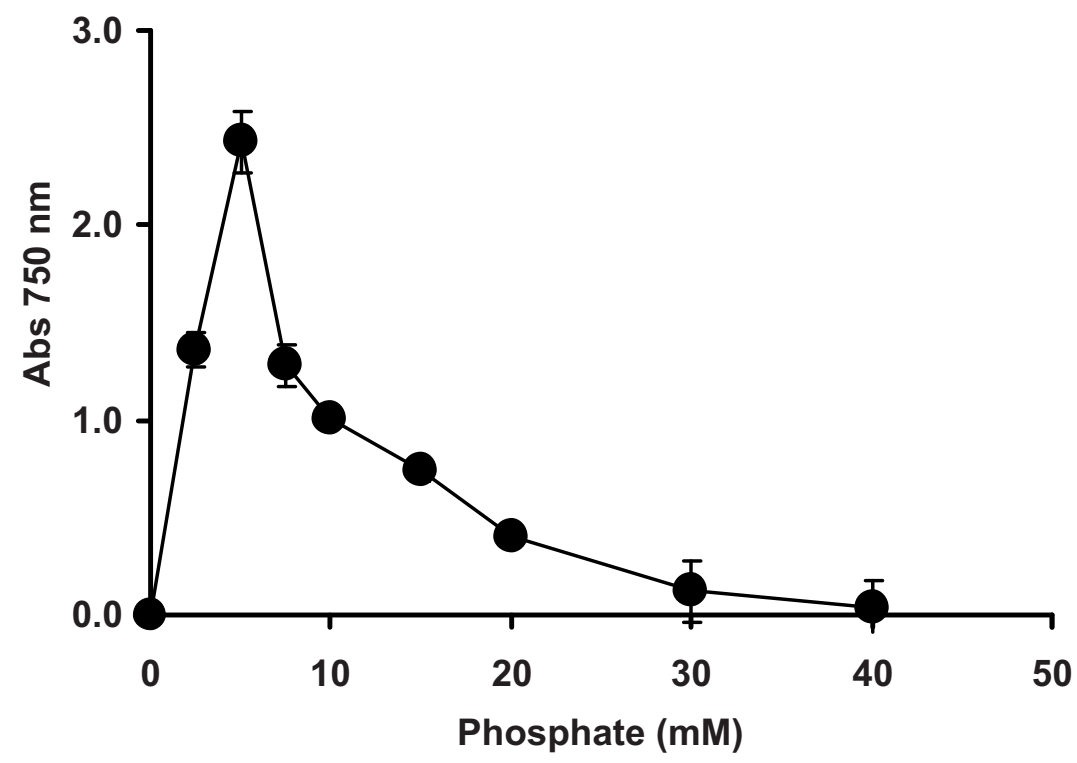

Figure 6 Molybdenum reduction by Enterobacter sp. strain Saw-2 at various phosphate concentrations Note: Error bars represent mean \pm standard deviation $(\mathrm{n}=3)$

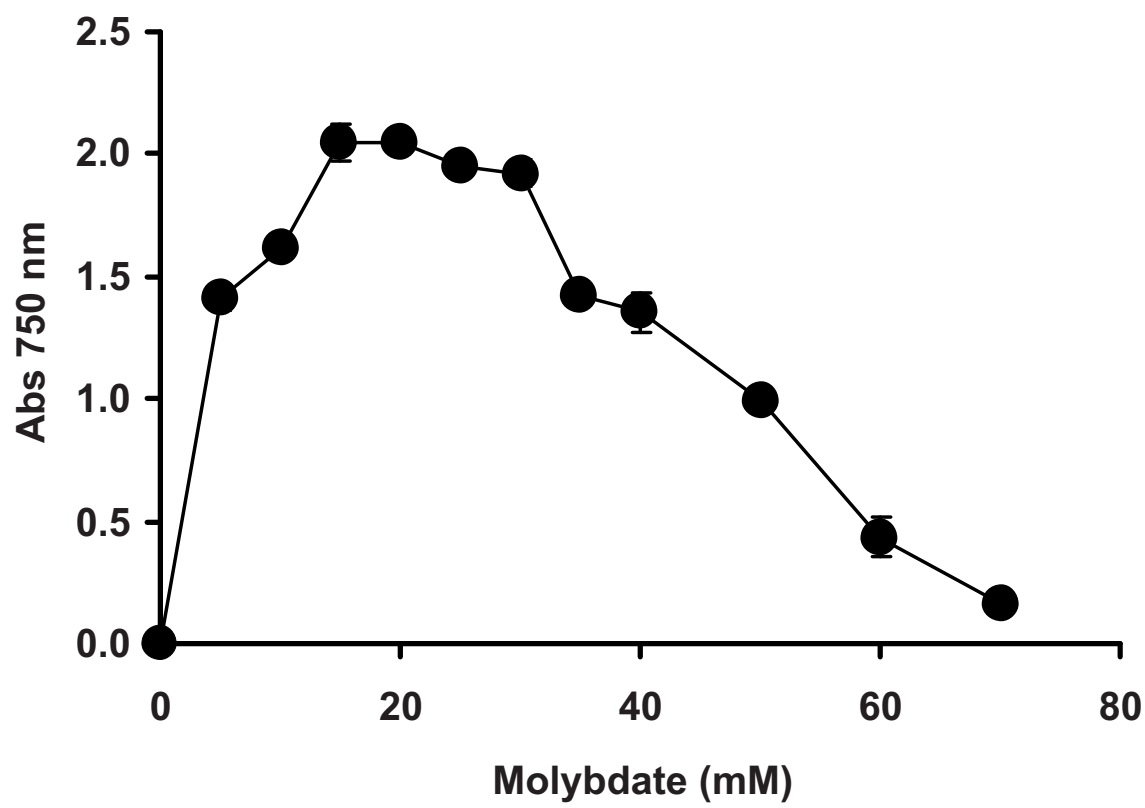

Figure 7 Molybdenum reduction by Enterobacter sp. strain Saw-2 at various sodium molybdate concentrations Note: Error bars represent mean \pm standard deviation $(\mathrm{n}=3)$ 
bacteria isolated to date, require optimal molybdate concentration between 10 and $80 \mathrm{mM}$ (Shukor, Rahman et al. 2010; Shukor \& Syed 2010; Lim et al. 2012; Ahmad et al. 2013; Halmi et al. 2013; Othman et al. 2013; Abo-Shakeer et al. 2013; Shukor et al. 2014). Reduction at these very high concentrations is an advantage for molybdenum bioremediation in an area having high concentration of this metal. For instance, in New Mexico where molybdenum concentration as high as 2,000 ppm or about $20 \mathrm{mM}$ was reported(Jacobs et al.2014).

\section{Effect of Heavy Metals}

Bacterial molybdate reduction to Mo-blue was inhibited by other heavy metals, which included cadmium (II), mercury (II), copper (II) and silver (I) at $2 \mathrm{ppm}$ with inhibition levels of 45.5, 36.8, 28.4 and $24.4 \%$, respectively. These inhibition levels were compared to control, which was assigned as having 100\% activity (Fig. 8).

Molybdate reduction to Mo-blue in many of the previously isolated Molybdenum-reducing bacteria were inhibited by similar toxic heavy metals (Shukor \& Syed 2010; Lim et al. 2012; Othman et al. 2013; Shukor et al. 2014). In hexavalent chromate reduction to the trivalent state by Bacillus sp. (Arutchelvan et al. 2006) and Enterobacter cloacae strain H01 (Rege et al. 1997), the metal ions of mercury and copper were strong inhibitors. The supposed target of these metals was chromate reductase. This enzyme utilized the electron donors NADH and NADPH to convert soluble toxic chromium $6+$ to the insoluble less toxic chromium 3+. Mercury binds strongly to sulfhydryl groups. Additionally, mercury also binds, with variable strength, to carboxyl, amide, phosphoryl and amine groups of protein. This is the reason why mercury is one of the most toxic metal ions known to human. Silver also binds to the sulfhydryl group of enzymes. Copper preferentially binds to cysteine, histidine and methionine residues of enzymes (Camakaris et al. 1999). The toxicity of these metal ions can be remedied through the addition of chemical additives including phosphate, calcium carbonate, manganese oxide and magnesium hydroxide (Hettiarachchi et al.2000; Deeb \& Altalhi 2009).

\section{Phenolics as Carbon Sources for Molybdenum Reduction and Independent Growth}

Preliminary screening works on phenolics as carbon sources supporting molybdenum reduction failed to give positive results (Data not shown). However, the bacterium was able to grow on the phenolic compounds (phenol and catechol) (Fig. 9).

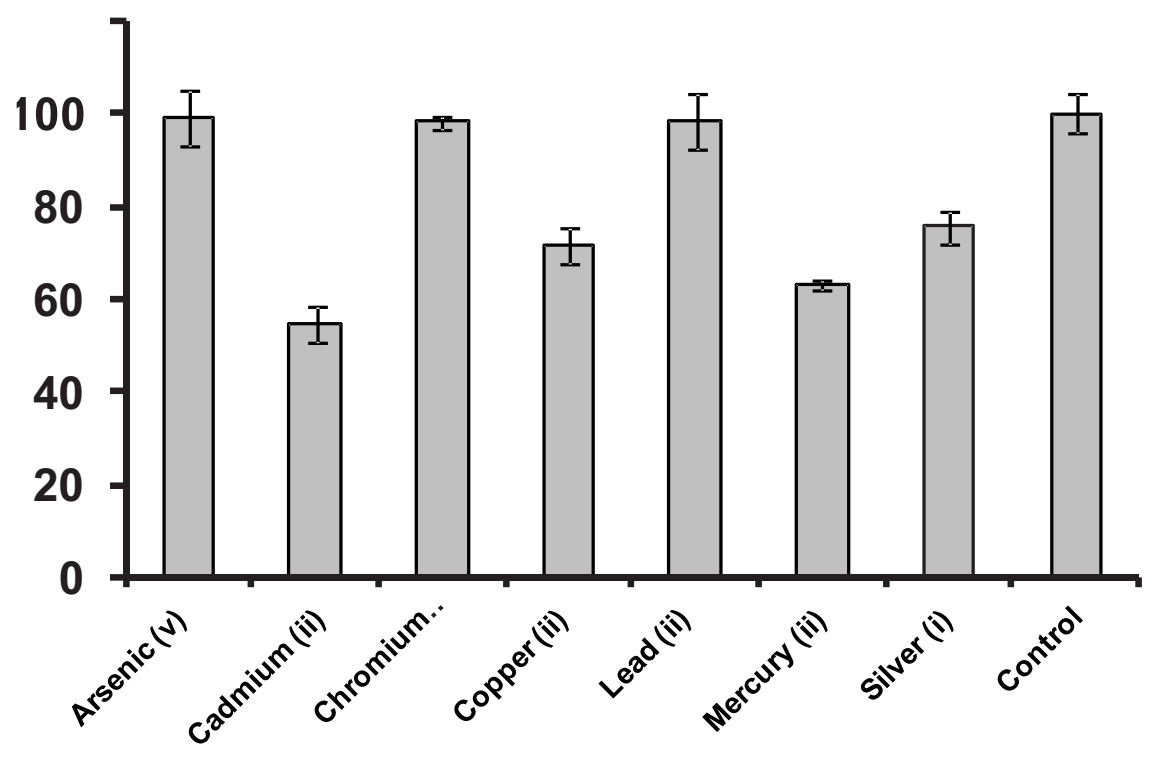

Figure 8 The effect of other heavy metals on Mo-blue production by Enterobacter sp. strain Saw-2 Note: Error bars represent mean \pm standard deviation $(\mathrm{n}=3)$ 


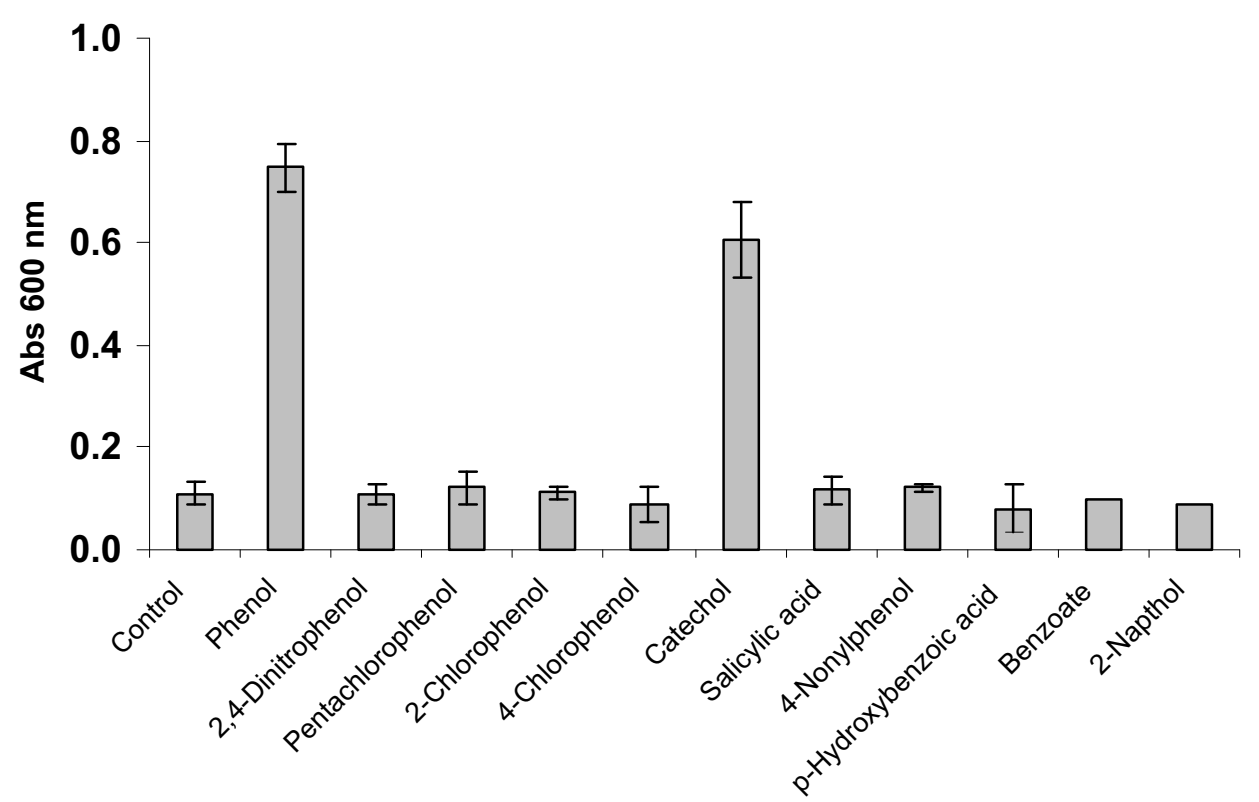

Figure 9 Growth of Enterobacter sp. strain Saw-2 on phenolics independent of molybdenum reduction Note: Error bars represent mean \pm standard deviation $(\mathrm{n}=3)$

Biodegradation of phenol and phenolic compounds by microorganisms has long been an object of research. Bacteria that could degrade phenol and phenolic compounds include Pseudomonas species (Folsom et al. 1990; Tomasi et al. 1995; Aravindhan et al. 2014; Hasan \& Jabeen 2015), Bacillus brevis (Arutchelvan et al. 2006), Alcaligenes sp. (Bai et al. 2007), Ocbrobactrum sp. (Kiliç 2009), Acinetobacter sp. (Ahmad et al. 2011; Yadzir et al. 2016) and Rhodococcus species (Arif et al. 2013).

\section{CONCLUSIONS}

Enterobacter sp. strain Saw-2 showed the novel ability to reduce heavy metal molybdenum to Mo-blue. This bacterium can also grow on the phenolic compounds (phenol and catechol). The identity of this bacterium is not completely robust; therefore, molecular identification is needed to further identify this species. This bacterium demonstrated a narrow $\mathrm{pH}$ and temperature ranges for optimal reduction. Glucose was the most effective electron donor for optimal molybdenum reduction. The bacterium needed a critical phosphate concentration of $5.0 \mathrm{mM}$. The optimal molybdate concentrations were between 15 and $30 \mathrm{mM}$. The absorption spectrum of the Mo-blue generated indicated that it was a reduced phosphomolybdate. Cadmium (II), mercury (II), copper (II) and silver (I) inhibited the process of molybdenum reduction to Mo-blue. Presently, efforts are ongoing to purify the Molybdenumreducing enzyme and to characterize phenolics biodegradation studies in greater detail. From bioremediation point of view, this reported bacterium might be an important bio-tool in reducing environmental pollutants like molybdenum.

\section{ACKNOWLEDGEMENTS}

This project was funded by the Research University Grant Scheme (RUGS), Project no. 0501-09-0750RU/F1.

\section{REFERENCES}

Abo-Shakeer LKA, Ahmad SA, Shukor MY, Shamaan NA, Syed MA. 2013. Isolation and characterization of a molybdenum-reducing Bacillus pumilus strain lbna. J Environ Microbiol Toxicol 1:9-14.

Ahmad SA, Shukor MY, Shamaan NA, Mac Cormack WP, Syed MA. 2013. Molybdate reduction to molybdenum blue by an Antarctic bacterium. Bio Med Res Int2013, Article number 871941. doi:10.1155/2013/871941.

Ahmad SA, Syed MA, Arif NM, Shukor MYA, Shamaan NA. 2011. Isolation, identification and characterization of elevated phenol degrading Acinetobactersp. strain AQ5NOL1. Aust J Basic Appl Sci 5:1035-45. 
Aravindhan R, Naveen N, Anand G, Rao JR, Nair BU. 2014. Kinetics of biodegradation of phenol and a polyphenolic compound by a mixed culture containing Pseudomonas aeruginosa and Bacillus subtilis. Appl Ecol Environ Res 12:615-25.

Arif NM, Ahmad SA, Syed MA, Shukor MY. 2013. Isolation and characterization of a phenol-degrading Rhodococcus sp. strain AQ5NOL 2 KCTC 11961BP. J Basic Microbiol 53:9-19.

Arutchelvan V, Kanakasabai V, Elangovan R, Nagarajan S, Muralikrishnan V. 2006. Kinetics of high strength phenol degradation using Bacillus brevis. J Hazard Mater 129:216-22.

Auffret MD, Yergeau E, Labbé D, Fayolle-Guichard F, Greer CW. 2015. Importance of Rhodococcus strains in a bacterial consortium degrading a mixture of hydrocarbons, gasoline, and diesel oil additives revealed by metatranscriptomic analysis. Appl Microbiol Biotechnol 99:2419-30.

Bai J, Wen JP, Li HM, Jiang Y. 2007. Kinetic modeling of growth and biodegradation of phenol and $\mathrm{m}$-cresol using Alcaligenes faecalis. Process Biochem 42:510-7.

Banerjee G, Pandey S, Ray AK, Kumar R. 2015. Bioremediation of heavy metals by a novel bacterial strain Enterobacter cloacae and its antioxidant enzymes activity, flocculants production and protein expression in presence of these heavy metals. Water Air Soil Poll 226:91-9.

Banerjee G, Pandey S, Ray AK, Kumar R. 2016. An alternative approach of water treatment by Arthrobacter phenanthrenivorans: Assessment of metal removal, surfactant production and oxidative stress. Curr Sci 110(11):2124-8.

Batta N, Subudhi S, Lal B, Devi A. 2013. Isolation of lead tolerant novel bacterial species, Achromobacter sp. TL-3: Assesment of bioflocculant activity. Indian J Exp Biol 51:1004-11.

Bi CM, Zhang YL, Liu FJ, Zhou TZ, Yang ZJ, Gao SY, Wang SD, Chen XL, Zhai XW, Ma XG, Jin LJ, Wang S. 2013. The effect of molybdenum on the in vitro development of mouse preimplantation embryos. Syst Biol Reprod Med 59(2):69-73.

Camakaris J, Voskoboinik I, Mercer JF. 1999. Molecular mechanisms of copper homeostasis. Biochem Biophys Res Commun 261:225-32.

Campbell AM, Del Campillo-Campbell A, Villaret DB. 1985. Molybdate reduction by Escherichia coli K-12 and its chl mutants. Proc Natl Acad Sci USA 82:227-31.

Clesceri LS, Greenberg AE, Trussell RR. 1989. Standard methods for the examination of water and wastewater. Baltimore (US):Port City Press. p. 4-166.

Costin S, Ionut S. 2015. ABIS online-bacterial identification software. Available from http://www.tgw1916. net/bacteria_logare.html, database version: Bacillus 022012-2.10. Retrieved on March 2015.
Davis GK. 1991. Molybdenum. In: Merian E, editor. Metals and their compounds in the environment, occurrence, analysis and biological relevance. New York (US): VCH Weinheim. p. 1089-100.

Daniels JN, Wuebbens MM, Rajagopalan KV, Schindelin H. 2008. Crystal structure of a molybdopterin synthase-precursor Z Complex: Insight into its sulfur transfer mechanism and its role in molybdenum cofactor deficiency. Biochemistry 47:615-26.

Deeb BE, Altalhi AD. 2009. Degradative plasmid and heavy metal resistance plasmid naturally coexist in phenol and cyanide assimilating bacteria. Am J Biochem Biotechnol 5:84-93.

Folsom BR, Chapman PJ, Pritchard PH. 1990. Phenol and trichloroethylene degradation by Pseudomonas cepacia G4: kinetics and interactions between substrates. Appl Environ Microbiol 56:1279-85.

Ghani B, Takai M, Hisham NZ, Kishimoto N, Ismail AKM, Tano T, Sugio T. 1993. Isolation and characterization of a Mo6+-reducing bacterium. Appl Environ Microbiol 59:1176-80.

Glenn JL, Crane FL. 1956. Studies on metalloflavoproteins. V. The action of silicomolybdate in the reduction of cytochrome $\mathrm{c}$ by aldehyde oxidase. Biochim Biophys Acta 22:111-5.

Halmi MIE, Zuhainis SW, Yusof MT, Shaharuddin NA, Helmi W, Shukor Y, Syed MA, Ahmad SA. 2013. Hexavalent molybdenum reduction to Mo-blue by a sodium-dodecyl-sulfate-degrading Klebsiella oxytoca strain DRY14. Bio Med Res Int 2013, Article number 384541. doi:2013:e384541.

Hasan SA, Jabeen S. 2015. Degradation kinetics and pathway of phenol by Pseudomonas and Bacillus species. Biotechnol Equip 29:45-53.

Hettiarachchi GM, Pierzynski GM, Ransom MD. 2000. In situ stabilization of soil lead using phosphorus and manganese oxide. Environ Sci Technol 34:4614-9.

Holt JG, Krieg NR, Sneath PHA, Staley JT. 1994. Williams ST. Bergey's manual of determinative bacteriology. $9^{\text {th }}$ edition. Baltimore (US): Lippincott Williams \& Wilkins. 787 p.

Hori T, Sugiyama M, Himeno S. 1988. Direct spectrophotometric determination of sulphate ion based on the formation of a blue molybdosulphate complex. Analyst 113:1639-42.

Iyamu EW, Asakura T, Woods GM. 2008. A colorimetric microplate assay method for high- throughput analysis of arginase activity in vitro. Anal Biochem 383:332-4.

Jacobs JA, Lehr JH, Testa SM. 2014. Acid mine drainage, rock drainage, and acid sulfate soils: causes, assessment, prediction, prevention, and remediation. Hoboken, New Jersey (US): John Wiley \& Sons, Inc. p. 30-52. 
Kazansky LP, Fedotov MA. 1980. Phosphorus- ${ }^{31}$ and oxygen $-{ }^{17}$ N.M.R. evidence of trapped electrons in reduced 18-molybdodiphosphate $(\mathrm{V}), \mathrm{P}_{2} \mathrm{Mo}_{18} \mathrm{O}_{62}{ }^{8-} \cdot \mathrm{J}$ Chem Soc Chem Commun: 644-6. doi: 10.1039/C39800000644.

Khan A, Halmi MIE, Shukor MY. 2014. Isolation of Moreducing bacterium in soils from Pakistan. J Environ Microbiol Toxicol 2:38-41.

Kiliç NK. 2009. Enhancement of phenol biodegradation by Ochrobactrum sp. isolated from industrial wastewaters. Int Biodeterior Biodegrad 63:778-81.

Leimkühler S, Wuebbens MM, Rajagopalan KV. 2011. The history of the discovery of the molybdenum cofactor and novel aspects of its biosynthesis in bacteria. Coord Chem Rev 255:1129-44.

Levine VE. 1925. The reducing properties of microorganisms with special reference to selenium compounds. J Bacteriol 10:217-63.

Lim HK, Syed MA, Shukor MY. 2012. Reduction of molybdate to molybdenum blue by Klebsiella sp. strain hkeem. J Basic Microbiol 52:296-305.

Llovera S, Bonet R, Simon-Pujol MD, Congregado F. 1993. Chromate reduction by resting cells of Agrobacterium radiobacter EPS-916. Appl Environ Microbiol 59:3516-8.

Losi ME, Jr W'TF. 1997. Reduction of selenium oxyanions by Enterobacter cloacae strain SLD1a-1: Reduction of selenate to selenite. Environ Toxicol Chem 16:1851-8.

Meeker JD, Rossano MG, Protas B, Diamond MP, Puscheck E, Daly D, ... Wirth JJ. 2008. Cadmium, lead, and other metals in relation to semen quality: Human evidence for molybdenum as a male reproductive toxicant. Environ Health Perspect 116:1473-9.

Myers CR, Carstens BP, Antholine WE, Myers JM. 2000. Chromium(VI) reductase activity is associated with the cytoplasmic membrane of anaerobically grown Shewanella putrefaciens MR-1. J Appl Microbiol 88:98-106.

Neunhäuserer C, Berreck M, Insam H. 2001. Remediation of soils contaminated with molybdenum using soil amendments and phytoremediation. Water Air Soil Poll 128:85-96.

Othman AR, Bakar NA, Halmi MIE, Johari WLW, Ahmad SA, Jirangon H, Syed MA, Shukor MY. 2013. Kinetics of molybdenum reduction to molybdenum blue by Bacillus sp. strain A.rzi. Bio Med Res Int. 2013, Article number 371058. doi:10.1155/2013/ 371058 .

Oves M, Khan MS, Zaidi A. 2013. Biosorption of heavy metals by Bacillus thuringiensis strain OSM29 originating from industrial effluent contaminated north Indian soil. Saudi J Biol Sci 20:121-9.

Rahman MFA, Shukor MY, Suhaili Z, Mustafa S, Shamaan NA, Syed MA. 2009. Reduction of Mo (VI) by the bacterium Serratia sp. strain DRY5. J Environ Biol 30:65-72.

Rege MA, Petersen JN, Johnstone DL, Turick CE, Yonge DR, Apel WA. 1997. Bacterial reduction of hexavalent chromium by Enterobacter cloacae strain H01 grown on sucrose. Biotechnol Lett 19:691-4.

Runnells DD, Kaback DS, Thurman EM. 1976. Geochemistry and sampling of molybdenum in sediments, soils, and plants in Colorado. In: Chappel WR, Peterson KK, editors. Molybdenum in the environment. New York (US): Marcel and Dekker, Inc.

Sedighi M, Vahabzadeh F. 2014. Kinetic Modeling of cometabolic degradation of ethanethiol and phenol by Ralstonia eutropha. Biotechnol Bioprocess Eng 19:239-49.

Shukor MS, Shukor MY. 2014. A microplate format for characterizing the growth of molybdenumreducing bacteria. J Environ Microbiol Toxicol $2: 42-4$.

Shukor MY, Habib SHM, Rahman MFA, Jirangon H, Abdullah MPA, Shamaan NA, Syed MA. 2008a. Hexavalent molybdenum reduction to molybdenum blue by $S$. marcescens strain Dr. Y6. Appl Biochem Biotechnol 149:33-43.

Shukor MY, Halmi MIE, Rahman MFA, Shamaan NA, Syed MA. 2014. Molybdenum reduction to molybdenum blue in Serratia sp. strain DRY5 is catalyzed by a novel molybdenum-reducing enzyme. BioMed Res Int. 2014, Article ID 853084. doi:10.1155/2014/ 853084 .

Shukor MY, Lee CH, Omar I, Karim MIA, Syed MA, Shaman NA. 2003. Isolation and characterization of a molybdenum-reducing enzyme in Enterobacter cloacae strain 48. Pertanika J Sci Technol 11:261-72.

Shukor MY, Rahman MFA, Shamaan NA, Lee CH, Karim MIA, Syed MA. 2008b. An improved enzyme assay for molybdenum-reducing activity in bacteria. Appl Biochem Biotechnol 144:293-300.

Shukor MY, Rahman MF, Shamaan NA, Syed MS. 2009. Reduction of molybdate to molybdenum blue by Enterobacter sp. strain Dr.Y13. J Basic Microbiol 49:S43-S54.

Shukor MY, Rahman MF, Suhaili Z, Shamaan NA, Syed MA. 2010. Hexavalent molybdenum reduction to Mo-blue by Acinetobacter calcoaceticus. Folia Microbiol (Praha) 55:137-43.

Shukor MY, Shamaan NA, Syed MA, Lee CH, Karim MIA. 2000. Characterization and quantification of molybdenum blue production in Enterobacter cloacae strain 48 using 12-molybdophosphate as the reference compound. Asia-Pac J Mol Biol Biotechnol 8:167-72.

Shukor MY, Syed, M.A. 2010. Microbiological reduction of hexavalent molybdenum to molybdenum blue. In: 
Vilas AM, editor. Microbiology Book Serial Number 2 "Current Research, Technology and Education Topics in Applied Microbiology and Microbial Biotechnology. Badajoz (ES): Formatex Research Center.

Shukor Y, Adam H, Ithnin K, Yunus I, Shamaan NA, Syed A. 2007. Molybdate reduction to molybdenum blue in microbe proceeds via a phosphomolybdate intermediate. J Biol Sci 7:1448-52.

Sidgwick NV. 1951. The chemical elements and their compounds. Oxford (US): Clarendon Press.

Sims RPA. 1961. Formation of heteropoly blue by some reduction procedures used in the microdetermination of phosphorus. Analyst 86(1026):584-90.

Sugio T, Tsujita Y, Katagiri T, Inagaki K, Tano T. 1988. Reduction of Mo6+ with elemental sulfur by Thiobacillusferrooxidans. J Bacteriol 170:5956-9.

Suzuki T, Miyata N, Horitsu H, Kawai K, Takamizawa K, Tai Y, Okazaki M. 1992. NAD $(\mathrm{P}) \mathrm{H}$-dependent chromium (VI) reductase of Pseudomonas ambigua G-1: A Cr (V) intermediate is formed during the reduction of $\mathrm{Cr}$ (VI) to $\mathrm{Cr}$ (III). J Bacteriol 174:5340-5.

Tomasi I, Artaud I, Bertheau Y, Mansuy D. 1995. Metabolism of polychlorinated phenols by
Pseudomonas cepacia AC1100: Determination of the first two steps and specific inhibitory effect of methimazole. J Bacteriol 177:307-11.

Ward GM. 1978. Molybdenum toxicity and hypo cuprosis in ruminants a review. J Anim Sci 46:1078-85.

Yadzir ZHM, Shukor MY, Ahmad A, Nazir MS, Shah SMU, Abdullah MA. 2016. Phenol removal by newly isolated Acinetobacter baumannii strain Serdang 1 in a packed-bed column reactor. Desalination Water Treat 57(28):13307-17. doi:10.1080/19443994. 2015.1063459 .

Yoshimura K, Ishii M, Tarutani T. 1986. Microdetermination of phosphate in water by gel-phase colorimetry with molybdenum blue. Anal Chem 58:591-4. 